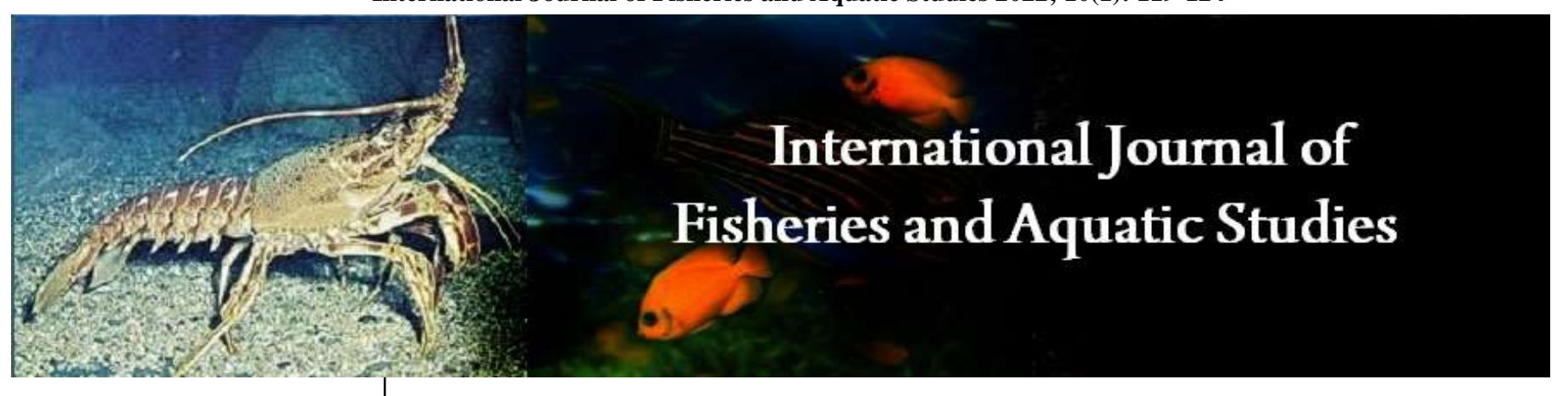

E-ISSN: 2347-5129

P-ISSN: 2394-0506

(ICV-Poland) Impact Value: 5.62

(GIF) Impact Factor: 0.549

IJFAS 2022; 10(1): 119-124

(C) 2021 IJFAS

www.fisheriesjournal.com

Received: 09-11-2021

Accepted: 12-12-2021

Sanjay Dey

Department of Zoology, Ananda

Mohan College, Kolkata, West

Bengal, India

Ashis Kumar Panigrahi

Eco-toxicology, Fisheries and

Aquaculture Extension

Laboratory, Department of

Zoology, University of Kalyani,

Kalyani, Nadia, West Bengal,

India
Corresponding Author:

Sanjay Dey

Department of Zoology, Ananda

Mohan College, Kolkata, West

Bengal, India

\section{Ichthyo-Diversity in different rivers of West Bengal, India: Status and conservation strategy}

\author{
Sanjay Dey and Ashis Kumar Panigrahi
}

DOI: https://doi.org/10.22271/fish.2022.v10.i1b.2630

\begin{abstract}
West Bengal is surrounded by many rivers. Rivers plays a decisive role in freshwater habitat and connects with ocean. But fish diversity knowledge is inadequate in different rivers of West Bengal. West Bengal provides $7.5 \%$ of resources of water of the country. West Bengal is fulfilled with many resources of water like, beel, pond, rivers. Freshwater diversity in rivers may loss due to anthropogenic effect and also by pollution. Besides this exploitation and change of climate are another major cause of biodiversity loss. Decreasing trend of fish diversity is a aggregate approach to conservation of fish diversity. For this reason riverine fishes are the threatened taxa. But less effort have been dedicated for conservation of river fishes this review helps to understand fish species in south and north Bengal rivers in West Bengal.
\end{abstract}

Keywords: Diverse, management, cryopreservation, fish safe zone, keystone, flagship, sustainability

\section{Introduction}

Fishes are most common and have diverse group. Lévêque et al., (2008) ${ }^{[14]}$ showed fish related research in India are exploratory stage. Fish base have 34700 species of fish and provides information to the researcher (Fish base). In West Bengal river Ganga is divided into two parts North Bengal and South Bengal. Southern part of West Bengal is called South Bengal. Some districts of South Bengal are Nadia, Howrah, Hooghly, East Midnapore, West Midnapore, etc. Some districts of Northern Bengal are Alipurduar, South Dinajpur, Coochbehar, etc. South Bengal and Northern Bengal have hotspot of fishes. Swain (2008) ${ }^{\text {32] }}$ identified freshwater ornamental habitats in India. Sarkar et al., (2015) ${ }^{[26]}$ studied diversity of ornamental fish in Torsa river and Gargharia river. Agriculture and rivers are directly interlinked in West Bengal. West Bengal act as rivers land. Due to irrigation from tributaries of the river Ganga, number of fish species have been decreased (Payne et al., 2004) ${ }^{[22]}$. Lakra et al., (2010) ${ }^{[13]}$ showed from river Ganga 29 fish species were recorded as threatened category.

Freshwater fish species mainly loss due to Industries (Gibbs 2000) ${ }^{[9]}$ and they are the menace group (Darwall and Vie 2005) ${ }^{[4]}$. Management of fish habitats is a challenge now days (Dudgeon et al., 2006) ${ }^{[7]}$. Researcher showed ichthyofaunal diversity in many reservoirs and lakes (Patra 2006, Mahapatra 2003) ${ }^{[19,17]}$. Different estuarine system provides significant production of fisheries (Sugunan and Sinha 2001) ${ }^{[30]}$. In India conservation and management of rivers have insufficient information. Proper planning of conservation is essential to save freshwater biodiversity (Pusey et al., 2010, Lipsey and Child 2007) ${ }^{[23,15] .}$

\section{Rivers in West Bengal}

Many important river flows inside the West Bengal. Some of them are Bhagirathi Hooghly, Dwarakeshwar, Churni, Barakar, Jaldhaka, Mahananda, Kangsabati, etc. West Bengal consists of many rivers. Bhagirathi Hooghly and Ganga Padma rivers tributaries are the major rivers in West Bengal. Some Himalayan rivers that flows through West Bengal are Tista, Mahananda Jaldhaka, Torsa, etc. From the Chotonagpur plateau some river arises. They are Damodar, Rupnarayan, Ajay, Haldi, Subarnarekha, etc. Some tidal river like Matla flows through West Bengal. In West Bengal tidal rivers are present in Sundarban area like, Gosaba, Kultali, etc. Main problem of tidal river is they overflow bank during the high tide. 


\section{Fish diversity in Damodar River}

Saha and Patra (2013) ${ }^{[25]}$ showed fish diversity in Damodar river. In Daomodar 46 species of fishes were present during January 2011-2012 (Saha and Patra, 2013) ${ }^{[25]}$. Saha and Patro (2013) [25] reported $38 \%$ fish belongs to order Cyprinidontiforms, 30\% fish belongs to order Perciformes, 26 $\%$ fish belongs to order Siluriformes in Damodar river. Highest fish diversity Index was observed in Barsul (0.97) followed by Krisak setu (0.96) and Palla (0.95) (Saha and Patra, 2013) ${ }^{[25]}$. Oranamenta fish diversity in Damodar river have been identified by Sarkar L (2020) ${ }^{[29]}$.

\section{Fish diversity in Churni river}

In river Churni 48 species have been reported which belongs to 18 families, 29 genera, 8 orders (Bhakta and Bandyopadhyay, 2007) ${ }^{[2]}$. Highest population of fish that were present in river Churni are Oreochromis mossambicus, Cyprinus carpio and lowest population fish is Clarias gariepinus (Bhakta and Banyopadhyay, 2007) ${ }^{[2]}$

\section{Fish diversity in Kangsabati River}

n Kangsabati river, 46 fish species have been recorded including 17 families, 29 genera, 8 orders during August 2013 to January 2015 (Kar et al., 2016) ${ }^{[12]}$. According to Kar et al., (2016) [12] in Kangsabati river $41 \%$ fish species were Cypriniformes, $18 \%$ fish species were Perciformes, $28 \%$ fish species were Siluriformes. Highest fish diversity Index was observed in Pathra River Bank (3.30) followed by Sal Dahari river bank (3.26), Balishira river bank (3.04), Payraguri river bank (2.92), Najargunj (2.66) (Kar et al., 2016) ${ }^{[12]}$.

Table 1: Annual estimated discharge $(\mathrm{mcm})$ of some rivers in West Bengal (Rudra, 2016) ${ }^{[24]}$

\begin{tabular}{|c|c|}
\hline River & Estimated discharge (mcm) \\
\hline Teesta & 29947 \\
\hline Mahananda & 23129 \\
\hline Jaldhaka & 17212 \\
\hline Torsa & 23097 \\
\hline Ganga at Farakka & 513100 \\
\hline
\end{tabular}

Table 2: List of fish species found in Hooghly river (Nath and Patra, 2015) [18]

\begin{tabular}{|c|c|}
\hline Scientific name & Frequency occurrance \\
\hline Rhinomugil corsula & $30-40 \%$ in the catch \\
\hline Sicamugil cascasia & Occur very occasionally \\
\hline Channa Punctatus & $5-10 \%$ in the catch \\
\hline Channa orientalis & $5-10 \%$ in the catch \\
\hline Pseudambasis ranga & $1-5 \%$ in the catch \\
\hline Jhonius gangeticus & $5-10 \%$ in the catch \\
\hline Trichogaster fasciatus & $5-10 \%$ in the catch \\
\hline Glossogobius giuris & $30-40 \%$ in the catch \\
\hline Periopthalmodon $\mathrm{sp}$. & Occur very occasionally \\
\hline Pseudapocryptes lanceolatus & $30-40 \%$ in the catch \\
\hline Odontamblyopus rubicundus & $30-40 \%$ in the catch \\
\hline Apocryptes bato & $5-10 \%$ in the catch \\
\hline Platycephalus indicus & $30-40 \%$ in the catch \\
\hline Datnioides quadrifasciata & Occur very occasionally \\
\hline Macrognathus aral & Occur very occasionally \\
\hline Macrognathus pancalus & Occur very occasionally \\
\hline Mastacembelus armatus & Occur very occasionally \\
\hline Sillaginopsis panijus & $10-30 \%$ in the catch \\
\hline Badis badis & Occur very occasionally \\
\hline Eleotris fusca & $10-30 \%$ in the catch \\
\hline Acanthopagrus latus & Occur very occasionally \\
\hline Nandus nandus & Occur very occasionally \\
\hline Polynemus paradiseus & Occur very occasionally \\
\hline Scatophagus argus & Occur very occasionally \\
\hline Tilapia nylotica & Occur very occasionally \\
\hline Etroplus suratensis & Occur very occasionally \\
\hline Lates calcarifer & Occur very occasionally \\
\hline Ompok pabda & Occur very occasionally \\
\hline Wallago attu & Occur very occasionally \\
\hline Mystus cavasius & $10-30 \%$ in the catch \\
\hline Mystus vittatus & $1-5 \%$ in the catch \\
\hline Mystus bleekari & Occur very occasionally \\
\hline M gulo & $1-5 \%$ in the catch \\
\hline Sperata aor & $1-5 \%$ in the catch \\
\hline Sperata seeghala & $1-5 \%$ in the catch \\
\hline Rita rita & $5-10 \%$ in the catch \\
\hline Rita gogra & $30-40 \%$ in the catch \\
\hline Gagata gagata & Occur very occasionally \\
\hline Gagata sexualis & Occur very occasionally \\
\hline Gagata cenia & Occur very occasionally \\
\hline Bagarius bagarius & Occur very occasionally \\
\hline Glyptothorax telchitta & Occur very occasionally \\
\hline Entropichthys vacha & $30-40 \%$ in the catch \\
\hline Silonia silonida & $1-5 \%$ in the catch \\
\hline Eutropichthys murius & Occur very occasionally \\
\hline
\end{tabular}




\begin{tabular}{|c|c|}
\hline Ailia colia & $30-40 \%$ in the catch \\
\hline Clupisoma garua & $30-40 \%$ in the catch \\
\hline Neotropius atherinoides & $1-5 \%$ in the catch \\
\hline Secutor ruconis & $5-10 \%$ in the catch \\
\hline Heteropneustes fossilis & $5-10 \%$ in the catch \\
\hline Pangasius pangasius & Occur very occasionally \\
\hline Gerres oyena & $1-5 \%$ in the catch \\
\hline Esomus damricus & Occur very occasionally \\
\hline Amblypharyngodon mola & $1-5 \%$ in the catch \\
\hline Puntius conchonius & $5-10 \%$ in the catch \\
\hline Puntis ticto & Occur very occasionally \\
\hline Ostebrama cotio cotio & Occur very occasionally \\
\hline Laubuca laubuca & Occur very occasionally \\
\hline Cirrhinus reba & Occur very occasionally \\
\hline Cirrihinus mrigala & $10-30 \%$ in the catch \\
\hline Salmophasia phulo & $10-30 \%$ in the catch \\
\hline Salmophasia bacaila & $10-30 \%$ in the catch \\
\hline Labeo calbasu & $5-10 \%$ in the catch \\
\hline Hypophthalmichtys molitrix & Occur very occasionally \\
\hline Labeo rohita & Occur very occasionally \\
\hline Labeo bata & $5-10 \%$ in the catch \\
\hline Catla catla & Occur very occasionally \\
\hline Rasbora sp. & Occur very occasionally \\
\hline Chagunius chagunio & Occur very occasionally \\
\hline Lepidocephalichthys guntea & Occur very occasionally \\
\hline Tenualosa lisha (juvenile) & $30-40 \%$ in the catch \\
\hline Tenualosa ilisa (adult) & $1-5 \%$ in the catch \\
\hline Gudusia chapra & $5-10 \%$ in the catch \\
\hline Corcia soborna & $30-40 \%$ in the catch \\
\hline Setipinna phasa & $30-40 \%$ in the catch \\
\hline Xenentodon concila & Occur very occasionally \\
\hline Hemiramphus far & Occur very occasionally \\
\hline Aplocheilus panchax & Occur very occasionally \\
\hline Pisodonophis boro & $10-30 \%$ in the catch \\
\hline Anguilla bengalensis bengalensis & $5-10 \%$ in the catch \\
\hline Amphipnous cuchia & Occur very occasionally \\
\hline Cynoglossus cynoglossus & $5-10 \%$ in the catch \\
\hline Euryglossa orientalis & $10-30 \%$ in the catch \\
\hline Microphis cuncalus & Occur very occasionally \\
\hline Tetradon cutcutia & Occur very occasionally \\
\hline Notopterus notopterus & Occur very occasionally \\
\hline Notopterus chitala & Occur very occasionally \\
\hline Crocodile fish Pterygoplichthys sp. & Occur very occasionally \\
\hline
\end{tabular}

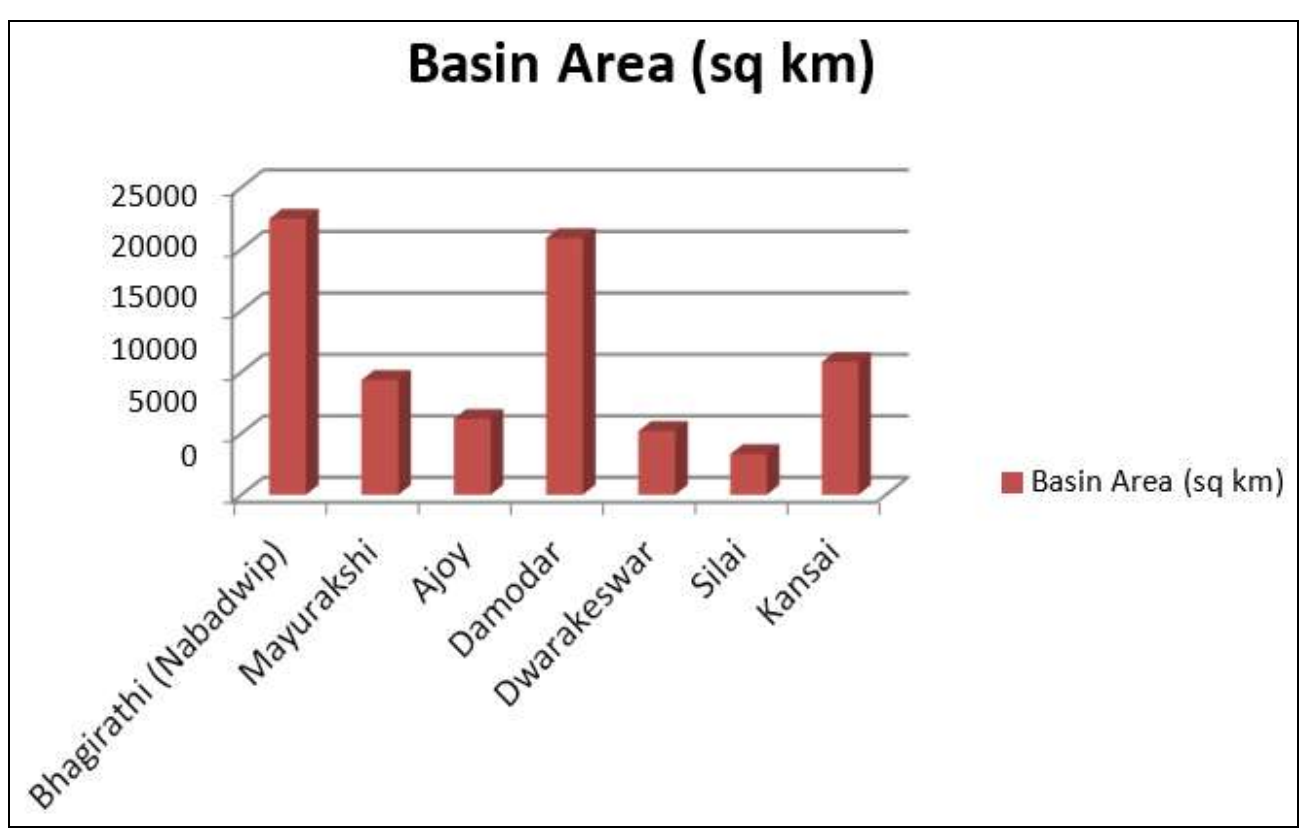

Fig 1: Basin area (sq. km.) of Bhagirathi (Nabadwip), Mayurakshi, Ajoy, Damodar (Jamalpur), Dwarakeswar, Silai, Kansai (Rudra. 2016) ${ }^{\text {[24] }}$ 


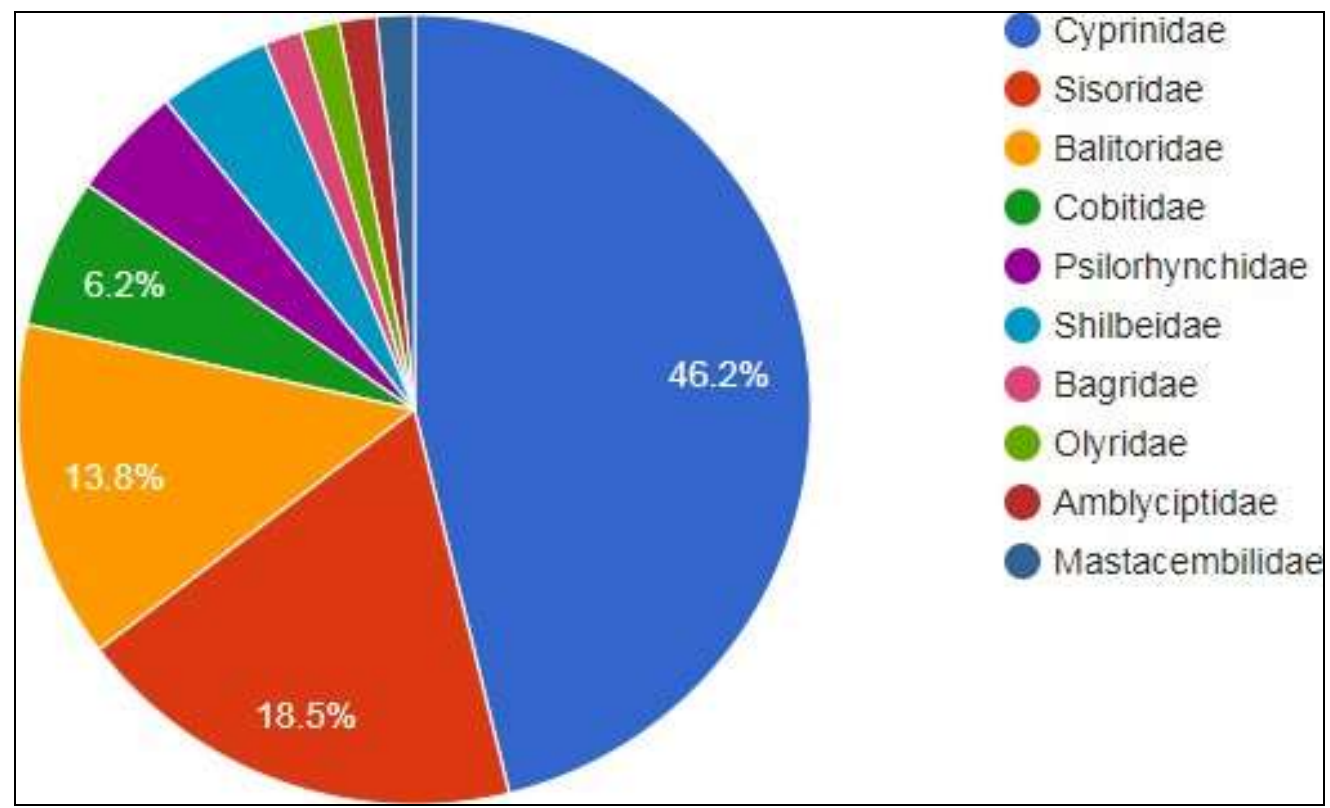

Fig 2: Family wise distribution of fish species in Teesta river (Acharjee and Barat, 2013) ${ }^{[1]}$

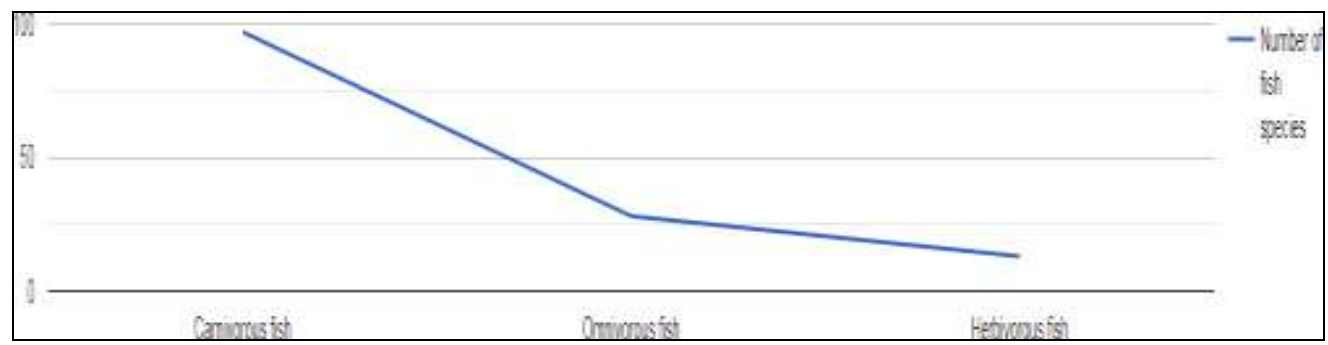

Fig 3: Economic importance of fish species in Kaljani river (Dey et al., 2015) [5, 6]

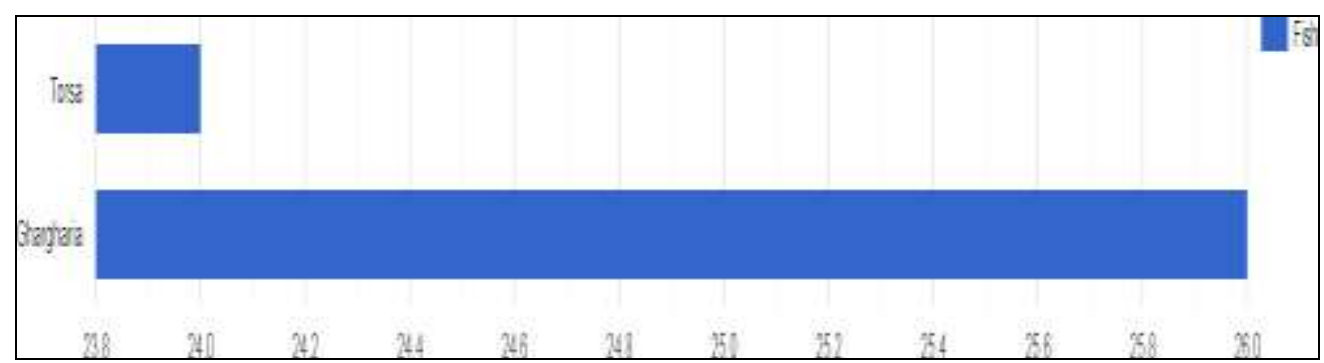

Fig 4: Ornamental fish species in Torsa and Ghargharia river (Sarkar et al., 2015) ${ }^{[26]}$

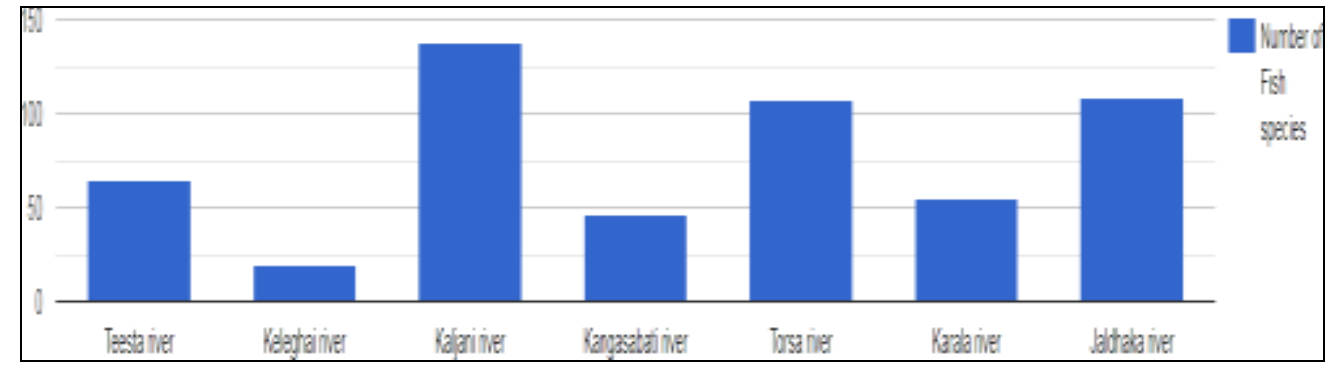

Fig 5: Fish species present in different rivers (Acharjee and Barat 2013, Jana et al., 2015, Dey et al., 2015, Kar et al., 2016, Dey and sarkar 2015, Patra et al., 2011, Sarkar and Pal 2018) ${ }^{[1,11,5,6,12,26]}$

\section{Conservation Strategy}

Conservation of fish species in Guadiana River was reported by Filipe at al., (2004) ${ }^{[8]}$. Cooke et al., (2012) ${ }^{[3]}$ showed some factors that hampers the conservation of endangered fish species in rivers. According to Madhavi et al., (2012) ${ }^{[16]}$ some conservation strategy are

a) For conservation of gene by cryopreservation method gene bank plays a pivotal role. b) Mass awareness among the common people must be increased.

c) For conservation of fish species application of Geographic information system must be expanded.

Freshwater Fish Safe Zone is an idea for maintenance of biodiversity and conservation (Gupta et al., 2014) ${ }^{[10]}$. Some important strategy for Freshwater Fish Safe Zone is as follows 
(Gupta et al., 2014) ${ }^{[10]}$

a) To protect the habitat of fish species Freshwater Fish Safe Zone must be carefully maintained.

b) Freshwater Fish Safe Zone should be outlined into two parts; core area and buffer area.

c) Deforestation and agricultural practice should be stopped in the terrestrial area near the river.

d) Research and field study should meticulously maintain.

e) To identify the connection between Keystone and Flagship species with Freshwater Fish Safe Zone for Conservation purpose.

\section{Conclusions}

In this study we found many fish species in different rivers of Wet Bengal. Wet Bengal's river is regarded as hot spot of fish species. But due to pollution, flood fish diversity has been reduced. Besides this indiscriminate killing is another cause for threatening of freshwater biodiversity. Conservation helps to maintain freshwater biodiversity. So there is a need for conservation strategy to protect the freshwater diversity. In situ conservation is an key step for sustainability. Beside this proper planning and people's awareness are the important step to conserve biodiversity.

\section{Acknowledgements}

The Authors would like to show thanks to the authorities of Department of Zoology, University of Kalyani for their cordial support in carrying out the research.

\section{References}

1. Acharjee ML, Barat S. Ichthyofaunal Diversity of Teesta River in Darjeeling Himalaya of West Bengal, India. Asian Journal of Experimental Biological Sciences, 2013;4(1):112-122.

2. Bhakta JN, Bandyopadhyay PK. Exotic fish biodiversity in Churni River of west Bengal, India. Electronic Journal of Biology. 2007;3(1):13-17.

3. Cooke SJ, Paukert C, Hogan Z. Endangered river fish: factors hindering conservation and restoration. Endangered species research. 2012;17(2):179-191.

4. Darwall WRT, Vie JC. Identifying important sites for conservation of freshwater biodiversity: extending the speciesbased approach. Fish Manag Ecol 2005;12:287293.

5. Dey A, Sarkar D. In search of Ichthyofauna diversity: A study on Torsa river in Cooch Behar district of West Bengal. Int. J. Pure App. Biosci. 2015;3(4):235-241.

6. Dey A, Nur R, Sarkar D, Barat S. Ichthyofauna Diversity of River Kaljani in Cooch Behar District of West Bengal, India. Int. J. Pure App. Biosci. 2015;3(1):247-256.

7. Dudgeon D, Arthington AH, Gessner MO, Kawabata ZI, Knowler DJ, Leveque C et al. Freshwater biodiversity: importance, sthreats, status and conservation challenges. Biol Rev 2006;81:163-182.

8. Filipe AF, Marques TA, Seabra S, Tiago P, Ribeiro F, Da Costa LM et al. Selection of priority areas for fish conservation in Guadiana River Basin, Iberian Peninsula. Conservation Biology. 2004;18(1):189-200.

9. Gibbs JP. Wetland loss and biodiversity conservation. Conserv Biol 2000;14(1):314-317.

10. Gupta N, Raghavan R, Sivakumar K, Mathur VB. Freshwater fish safe zones: a prospective conservation strategy for river ecosystems in India. Current Science, 2014;107(6):949-950.
11. Jana A, Sit G, Maiti K. Ichthyofaunal diversity of Keleghai river at Medinipur district in West Bengal. International Research Journal of Basic and Applied Sciences. 2015;1:24-26.

12. Kar A, Bhattacharya M, Ghorai M, Patra S, Patra BC. December. Ichthyofaunal Diversity of Kangsabati River at Paschim Medinipur District, West Bengal, India. In Proceedings of the zoological society Springer India. 2016;70(2):165-173.

13. Lakra WS, Sarkar UK, Gopalakrishnan A, Pandian AK. Threatened freshwater fishes of India. NBFGR publication, Lucknow. 2010.

14. Lévêque C, Oberdorff T, Paugy D, Stiassny MLJ, Tedesco PA. Global diversity of fish (Pisces) in freshwater. Hydrobiologia. 2008;595:545-567.

15. Lipsey MK, Child MF. Combining the fields of reintroduction biology and restoration ecology. Conserv Biol 2007;21:1387-1388.

16. Madhavi VK, Reddy VDA, Reddy VG. Conservation of Fish Faunastic Diversity-An Indian Perspective. European Journal of Zoological Research. 2012;1(3):8085.

17. Mahapatra DK. "Present status of fisheries of Hirakund Reservoir, Orissa," Fishing Chimes, 2003;22(10, 11):7679.

18. Nath AK, Patra A. Survey on the present status of Fish species diversity in a stretch of Hooghly river of West Bengal, India. International Journal of Fisheries and Aquatic Studies. 2015;3(1):244-250.

19. Patra S. Studies on the biological aspects of Ansupa Lake, Orissa (India) [Ph.D. thesis], Utkal University, Bhubaneswar, India. 2006.

20. Patra AK, Sengupta S, Datta T. Physico-Chemical Properties And Ichthyofauna Diversity In Karala River, A Tributary Of Teesta. 2011.

21. River At Jalpaiguri District of West Bengal, India. International Journal of Applied Biology and Pharmaceutical Technology, ISSN 0976 - 4550. Volume: 2011;2(3).

22. Payne AI, Sinha RK, Singh HR, Haq S. A review of theGanges Basin: its fish and fisheries. In: Welcomme RL, Peter T (eds) Proceedings of the second international symposium on the management of large rivers for Fisheries, FAO Regional Office for Asia and the Pacific, Bangkok, Thailand. 2004;1:229-251.

23. Pusey BJ, Arthington AH, Stewart-Koster B, Kennard MJ, Read MG. Widespread omnivory and low temporal and spatial variation in the diet of fishes in a hydrologically variable northern Australian river. J Fish Biol 2010;77:731-753.

24. Rudra K. State of India's river for India rivers week. 2016.

25. Saha MK, Patra BC. Present status of ichthyofaunal diversity of Damodar river at Burdwan district, West Bengal, India. International journal of scientific research publications. 2013;3(6):1-11.

26. Sarkar D, Dey A, Ray N. Indigenous Ornamental Fish Diversity in Torsa and Ghargharia: Nature's Conservation Strategy. J. Agric. Technol. 2015;2(1, 2):21-27.

27. Sarkar T, Pal J. Diversity and conservation status of Ichthyofauna in the river Jaldhaka, West Bengal. 2018.

28. International Journal of Fisheries and Aquatic Studies 2018;6(2):339-345. 
29. Sarkar L. Study of Diversity of Ornamental Fishes from Some Selected Sites of Damodar River System. Journal of Environment and Sociobiology. 2020;17(1):19-26.

30. Sugunan VV, Sinha M. Sustainable capture and culturebased fisheries in freshwaters of India. In: T.J. Pandian. 2001.

31. (Ed.), Sustainable Indian Fisheries, National Academy of Agricultural Sciences, New Delhi. 2001, 43-70.

32. Swain SK. "Indigenous Ornamental Fish and Their Export Potential", Originally Published as a Research Article in 8th Indian Fisheries Forum Souvenier Article. 2008.

33. www.fishbase.org 